\title{
THE MEANING OF TRUST AS A SOCIAL CAPITAL IN A RAMBU SOLO' CEREMONY AT TORAJA COMMUNITY IN THE SALU BELA’ DEVELOPMENT
}

\author{
Anita De Grave', Ratna Ayu Damayanti ${ }^{2}$, Syamsuddin $^{2}$ \\ ${ }^{1}$ Magister of Accounting Program, Faculty of Economics and Business, University of Hasanuddin, Indonesia \\ ${ }^{2}$ Department Magister of Accounting, Faculty of Economics and Business, University of Hasanuddin, Indonesia
}

\author{
DOI: $10.31364 / S C I R J / v 7 . i 4.2019 . P 0419635$ \\ http://dx.doi.org/10.31364/SCIRJ/v7.i4.2019.P0419635
}

\begin{abstract}
This study aims to reveal in depth the meaning of the trust value in the Rambu Solo' ceremony according to the Toraja people's understanding based on the practice of accounting for life. This study uses ethnometodology methods to achieve established research goals. By using an etho-methodological approach, this study seeks to uncover the meaning of trust in the traditional celebration of Rambu Solo' Toraja community. The ethnometodology approach seeks to understand how people perceive, explain and describe their own life order. Ethnometodology seeks to understand how people begin to see, explain, and describe the order of the world in which they live. The results of the study illustrate that the trust value for the Toraja community in the Rambu Solo' ceremony means that the value of honesty and trust is one of the foundations for the implementation of a solo sign, in which the process of receiving a family ceremony, there is no agreement and there is no record between the giver and the recipient, but each delivery will be returned when the person who gives the same ceremony.
\end{abstract}

Keywords: trust, social capital, Rambu Solo', ethnometodology.

\section{INTRODUCTION}

Research on behavior in accounting has enriched the accounting discipline itself and shows that accounting is not just a technical problem, but sees accounting more broadly than psychological considerations that influence the preparation of accounting reports to consider the socio-political role of accounting in organizations and society. Based on these studies, evolution in accounting is influenced by different environmental factors, where culture is the most important social factor (Noravesh, et al., 2007). However, the facts show that accounting research in Indonesia is still dominated by technical problems and tends to ignore the cultural values inherent in Indonesia (Chariri, 2009).

Accounting as a science and a tool that aims to make it easier for humans, of course, must submit to "how people live their lives", because if not, then accounting will not be useful to the user community. The problem is, every society in the world has a different perspective on how they should live their lives. For this reason, culture as a social aspect greatly influences the development of accounting, where accounting itself is part of social science.

Communities as cultural actors have a desire to cling to the traditions in their area. This also happened in several regions in Indonesia, one of them being the Toraja region. The Toraja community is one of the cultural actors who always cling to the traditions inherited from their ancestors. The inherited traditions are traditional ceremonies, such as birth ceremonies, wedding ceremonies, death ceremonies and others.

The Rambu Solo' ceremony for Toraja people is a culture that has the highest value compared to other cultural elements. For the Toraja community, speaking of funerals is not only about ceremonies, social status, the number of buffaloes cut, but more on self-esteem, shame (siri'). This is what causing the Rambu Solo' ceremony is not only related to the level of social stratification, but there is something more important than that, namely how to maintain and maintain the fabric of brotherly relationships within the family that remain interrupted. This is a strong reason why the Rambu Solo' ceremony should continue to be carried out for the Toraja community.

Damayanti et al., (2017) suggested that what determines the development of civilization is local wisdom that contains elements of creative intelligence and local knowledge from the elite and society. According to Damayanti (2009) socio-cultural values are the identity of a chain that connects the socio-cultural values of the past with the present. Because accounting users can form and be shaped by the environment, accounting can be seen as a socially formed reality and as a subject of political, economic and social pressure (Chariri, 2009). In recent years, interest in studying accounting from the behavioral and social side has increased. 
The dimension of social capital illustrates everything that makes society allied to achieve a common goal on the basis of togetherness, and in it is bound by values and norms that grow and are obeyed, and social inherent in the structure of social relations and social networks within a society that creates various kinds of social obligations, creating a climate of mutual trust, bringing information channels, and establishing norms, as well as social sanctions for members of the community (Coleman, 1999). However, Fukuyama (2000) firmly states, it is not necessarily shared norms and values that are guided as references to acting, acting, and acting that automatically become social capital. But it will only be shared norms and values that are generated by trust. Where this trust is expectations of order, honesty, and cooperative behavior that arise from within a community that is based on the norms shared by its members.

This study uses ethnometodology methods to achieve established research goals. By using an ethomo-methodological approach, this study seeks to uncover accounting practices in the celebration of the traditional Rambu Solo' Toraja community where accounting practices in the Rambu Solo' traditional ceremony are far different or in contrast to conventional or capitalist accounting practices currently practiced in Indonesia. The ethnometodology approach seeks to understand how people perceive, explain and describe their own life order. Ethnometodology seeks to understand how people begin to see, explain, and describe the order of the world in which they live.

Based on the description stated earlier, it can be understood that the main key problem lies in the extent to which the Toraja community understands the meaning of accounting practices that emerge at the Rambu Solo' ceremony. Therefore, the research question in this study is: How is the accounting practice in the Rambu Solo' ceremony Toraja community?.

This study aims to reveal in depth the understanding of the Toraja community regarding accounting practices in the Rambu Solo' ceremony. The results of this study are expected to contribute to both theoretical contributions (can increase understanding of accounting practices that are not only limited to material elements but there are non-material elements as well as add value in behavioral accounting science especially in the relationship between accounting and cultural practices) and practical contributions ( the community can understand the meaning of accounting practices in carrying out the Rambu Solo' ceremony).

\section{THEORETICAL REVIEW}

\section{Theory of Social Exchange}

Social exchange is a theory in the social sciences which states that in social relations there are elements of rewards, sacrifices, and benefits that influence each other. This theory explains how humans perceive our relationships with others in accordance with the human self's assumption about: the balance between what is given in the relationship and what is removed from the relationship, and the type of relationship that is carried out. Homans's theory of basic analysis is face-to-face social exchange between two individuals, with the concept of economic principles. Two individuals who hold interactions will always prioritize profits and minimize losses. Or also often called maximizing profit and minimizing loss. Homans states that society and social institutions really exist because of social exchange.

\section{Social Capital Theory}

The social capital theory was first discussed in 1916 (Lin, 2001). Contemporary social capital is offered first by Bourdie (1986) who says social capital is the whole source of actual or potential concepts, which are associated with ownership of a longlasting network or more or less reciprocal relationships between institutions that they know. Akdere (2005) shared social capital micro level and macro level. At the level of micro social capital level, social civil capital is related to values, beliefs, attitude, behavior of norms (Part, 2003). At present civil social capital is divided into three basic dimensions, namely; bonds, bridges, and relationships (lingkages). Bonds that describe close family relationships, close friends, and professional colleagues who help them. Bridges describe a rather distant relationship in order to apply it. Whereas, relations (lingkages) are described as vertical dimensions of social capital where there are parties who are not included in the power.

\section{Ethnometodology}

Ethnometodology is dedicated to explaining the ways in which community groups create, recognize subjects, the reality and flow of actions that are understood together. A deeper understanding of ethnometodology can be traced through Garfinkel's thinking which limits ethnometodology as an investigation of indexical phrases and other practical actions as a unity of organized daily life practices by leading to an explanation of "rational practical accountability" The explanation can be found through: 1) the difference between objective and indexical expressions, 2) reflexivity of various practical actions, and 3) the ability to analyze various actions that take place in the context of everyday life (Basrowi and Sudikin, 2002: 52; Poloma, 2007: 281 and Denzin and Lincoln, 2009: 339).

\section{RESEARCH METHODS}

This research is qualitative research (more aimed at achieving deep understanding of specific organizations or events) using the Ethnometodology approach. Ethnometodology research is carried out by researchers who aim to understand, change, and display new facts based on the desired daily environment of the object of research, namely the Toraja community in the lembang/village that has been studied. Ethnometodology research has results in the form of programs or principles of change and renewal. The purpose of using the method in this study is to uncover the meaning of accounting in the Rambu Solo' traditional ceremony.

In accordance with the ethnomethodology approach used in this study, the method of data collection was carried out by observation, documentation, and in-depth interviews by not closing the possibility that more complete research results would be carried out by historical documents relating to the Rambu Solo' traditional ceremony. The data collected in this research are data 
relating to accounting practices at the Rambu Solo' traditional ceremony in Lembang/Salu Bela Village in Sanggalangi District North Toraja Regency. Whereas the informants of this study can be seen in the following table.

Data Table of Research Informants

\begin{tabular}{|l|l|l|}
\hline No & Name of Informan & Explanation \\
\hline 1 & Mr Ta'dung & Customary Chief of Toparengge Lembang Salu Sopai \\
\hline 2 & Mr Roni & Head of Lembang Salu Bela’ \\
\hline 3 & Mr.Barto & Implementing Rambu Solo’ \\
\hline 4 & Mr.Lungan & Implementing Rambu Solo’ \\
\hline 5 & Mrs.Rita & Implementing Rambu Solo’ \\
\hline
\end{tabular}

Source: Data processed

\section{RESEARCH RESULTS AND DISCUSSION}

Humans always come into contact with culture. Therefore, humans are also referred to as cultural beings. There is no human in a society that has no culture and vice versa. Human culture manifested through values has colored the series of activities carried out. Cultural values play a role in determining ways of thinking and behaving. So that these values are actually present behind human behavior revealed through speech, deeds and material (Koentjaraningrat 2011: 92).

The Solo Signs Ceremony in terms of accounting practice is defined by the high costs and family debt. The cost is high because the procession is carried out lively and sacrifices a large amount of buffalo (tedong), in addition to the preparation process and other needs. In addition, there are also family debts that must be repaid when other families carry out this ceremony at a later time. This study looked at family debt in the Rambu Solo' ceremony from the social context as the social capital of the community. Debt that arises is social capital that arises from self-awareness of family and community communities without any request or bond agreement in it, without any interest or penalties that follow and the repayment period, as well as conventional debt practices that have been practiced so far.

The meaning of honesty is not just limited to the theory as saying the right, but also accompanied by responsibility for what is done in accordance with what has been chosen. Meanwhile dishonesty does not mean not saying the right thing but about the appearance that is not in accordance with the actual state of self, not sincere, pretending, and not willing to be responsible for what has become his choice. In the meaning of honesty as a strength of character also includes the understanding of how to carry out and accept the consequences of life choices. This is in line with what was stated by one of the supporting informants.

"... iyatu tomassuran with the task of lako te siulu 'is the oldest ketroroi lan tondok ...".

The meaning of reflexivity from the above statement delivered by Mr. Barto, shows the existence of a trust given to the oldest brother.

Furthermore, based on the results of the interview also found the meaning of honesty in the Rambu Solo' ceremony. 'Tae' ya, official registration between the recipient's family and the giver of the past when giving and receiving was limited to oral, but totemo denmo jomai toma'parenta minda-mindanna tu baa tedong, bai or iyaraka tu amplo' na iyya tu to diban natandaimo ya tu indanna umbanni sabak tannia to senga' siulu'na ri, iyaraka rarabukunna (family) is the most tangible'simisak-misa'ri", as explained by Mr. Lungan. (There are no official records in the implementing families of Solo Signs except pancatat from the government. Previously the issuance and receipt of debt was limited to verbal but now there are records from the government).

Based on the interview quote above, the expression of indexicality about the value of honesty and trust that underlies the implementation of the Rambu Solo' ceremony explicitly as said by Mr Lungan, can be reflected as a form of family trust as part of the assessment of the person and behavior of the person assigned to record. The phrase "totemo denmo cacatan jomai toma'parenta minda-mindanna tu baa tedong" indicates that there is no longer any debt acceptance done orally as was the practice in ancient times. With the development of the times, it was also developing the recording process. Even in some regions that carry out the Solo Signs ceremony, the registration process uses computerized equipment. In addition, the above expression shows the honesty values held by the people who carry out the Rambu Solo' ceremony.

What is illustrated above, gives a legitimacy that honesty encourages the formation of a strong person and raises awareness of the nature of life that matches the divine will. With personal and strong intentions, all obstacles will be passed successfully. That intention will affect the way a person works in various problems. Therefore, it is necessary to look for intentions that make every human being to be unsteady (Yulia, 2014: 13). The intention is the elements of faith that grow and are embedded in human beings that make each action based on the values of his faith (Jatmiko, 2012: 13).

Indeed, the human heart always feels the need for guidance from the Divine. This is an honest basic feeling that cannot be fulfilled except with a good relationship with God. This is where the role of worship is carried out properly. Families who hold the Rambu Solo' ceremony are not only Christians but also Muslims. Although different beliefs, but they still respect each other with one another with worship, which is one goal, namely to Sang.

Hinrichs (2000) and Winter (2003) state that economic relations are reflected in costs. Meanwhile, social relations are reflected through the bonds of local relations, trust and friendship which are seen as very important in shaping the sustainability of a business. Trust is a practice or approach used by a community to generate hope for each member of the community. Furthermore Cadilhon, et al. (2005) revealed that trust can create the reality of nature and the social world as a practice that occurs in a society and contributes to the creation of investment relations between parties involved in transactional relations.

The importance of trust is so important that Glasser et al. (2000) referred to by Leksono (2009: 121-122) revealed that trust is a basic capital that can strengthen social capital cohesion. Trust can give birth to hope. According to Widyosiswoyo (2004: 178) and Sujarwa (1999: 133), expectation (expectation) concerns the future that manifests the desire to be achieved in the future that is inseparable from one's present and past. 
Based on the description of the process of implementing the Rambu Solo' traditional ceremony, it can be explained the value of social capital (family debt) in the rules of indexicality and reflexivity in the following table.

Table of Indexicality Analysis and Reflection of Social Capital Value in Solo Sign Culture Frame

\begin{tabular}{|c|c|c|c|c|}
\hline Stages & Form & Data & Indexicality & Reflection \\
\hline $\begin{array}{l}\text { Honesty and } \\
\text { Trust }\end{array}$ & $\begin{array}{l}\text { Digging information } \\
\text { related to the value } \\
\text { of honesty and trust } \\
\text { in social debt at the } \\
\text { Rambu Solo' } \\
\text { ceremony }\end{array}$ & $\begin{array}{l}\text { The informant's phrase: } \\
\text { "... iyatu tomassuran with } \\
\text { the task of lako te siulu is } \\
\text { the oldest ketorroi lan } \\
\text { tondondok ..." (Barto) } \\
\text { "Tae' yes na official } \\
\text { registration between the } \\
\text { recipient's family and the } \\
\text { provider of the past when } \\
\text { giving and receiving was } \\
\text { only limited to oral" } \\
\text { (Lungan) }\end{array}$ & $\begin{array}{l}\text { The informants explicitly } \\
\text { stated that trust and honesty } \\
\text { underlie the activities of the } \\
\text { people who carry out the } \\
\text { Rambu Solo' ceremony } \\
\text { even since long ago }\end{array}$ & $\begin{array}{l}\text { The meaning of trust and } \\
\text { honesty is not only limited to } \\
\text { material values. The value of } \\
\text { trust and honesty is a } \\
\text { manifestation of family } \\
\text { accentuation as part of the } \\
\text { assessment of the personal } \\
\text { and living behavior of people } \\
\text { assigned to record. This } \\
\text { underlies every person who } \\
\text { carries out the Rambu Solo' } \\
\text { ceremony as a derivative of } \\
\text { ancestral values. }\end{array}$ \\
\hline
\end{tabular}

Source: data processed

The values of justice and truth are important and must be implemented in the lives of every human being. In QS. AlBaqarah (2) verse 29-30 states that in fact Allah will make humans as caliphs on earth to be valid and able to manage natural resources correctly and fairly because humans are khalifatullah. Recognizing the importance of human resources, organizations must be able to manage and utilize the potential of their human resources. The principle of "fair distribution" that is evenly distributed to all parties, including the community, is a "right" basis for accounting practice. Therefore a reform in the current form of accounting is needed so that it is more valuable "justice" (Sulistiyo, 2012: 22). The thought of the importance of the rules of balance in divine justice as a basis for revealing cultural meanings in the reality of accounting, becomes a strong impetus to interpret it on a broader scale. The principle of justice serves as an umbrella for the principle of truth and accountability. According to Muhammad (2000: 58) through the aspects of truth and accountability, the principle of justice can be enforced in the scope of accounting muamalah. So, with the existence of justice so that humans do not cross the line, with the existence of truth so that humans do not slip along the passions, with policies and prioritization so that humans are not afflicted with ego attitudes, and far from danger so that human nature does not become large.

Sulistiyo (2012) argues that the number of accounting and manipulation financial report scandals as well as the company's low awareness of social and environmental responsibility shows that there has been a change in the accounting actors. From this opinion, it can be concluded that the frauds that occur in accounting are mostly caused by the accounting actors. Accounting has been created so well, but when using accounting only based on its interests, accounting will also be used for the benefit of one group."Less intelligent can be improved by learning, less able to be eliminated by experience, but not honestly difficult to improve", is an expression conveyed by the first Indonesian Vice President Moh. Hatta (1902-1980) who described the high value of honesty.

Morality accompanied by the integration of spiritual values will be able to enlighten accounting actors towards God's love or Mahabbatullah (Mulawarman and Ludigdo, 2010). Spirituality is not only about religion but also about humanity and spirituality transcends religious boundaries and can be used to overcome life's problems (Eferin, 2015). Spiritual values are possessed by every human being, can be used as a basis in carrying out their obligations and responsibilities throughout their lives. Spiritual values will guide people to stay away from worldly misery.

Every human being has spiritual intelligence from birth and uses that intelligence to live life. Humans who have high spiritual intelligence will be able to provide a positive side in their lives so that people will always do good deeds and actions (Zohar and Marshall, 2001). The Vedanta philosophy proposed by Saraswati (1994) states that humans must be able to optimize the function of the mind (manah) who gets enlightenment from behavior (buddhi) and mental consciousness (atman) in order to control the body, mind and senses. Enlightenment from behavior and soul awareness can be achieved if humans have a good level of spirituality and morality.

Gilson (2006) states that the growth of trust occurs through a process of relationship risk taking behavior that illustrates that an individual allows themselves to be vulnerable by trusting their work partners. Furthermore, Cerri (2012) states that the concept of trust is the intention to accept vulnerabilities based on positive expectations of that intention. Social interaction provides the basis for building solid trust and reducing risk. An action that leads to a vulnerable behavior and intention to accept the vulnerability is rooted in positive expectations.

\section{CONCLUSIONS AND RECOMMENDATIONS}

The ritual of Rambu Solo' Toraja community is full of social values. The social values formed during this death ceremony, over time finally transformed into a tradition in the social order of the Toraja indigenous people. This is one of the factors that causes the Rambu Solo' rite to remain in the midst of changing times. The manifestation of trust values for the Toraja community in the Rambu Solo' ceremony means that the value of honesty and trust also underlies this ceremony, in which the process of receiving, recording, and recognizing debt is recorded as a whole so that each delivery will be returned when the ceremony takes same place. 
Reviewing the reality of cultural accounting practices in the Rambu Solo' ceremony interpreting the researcher that the values revealed in the practice of Rambu Solo' debt; in this research the tendency to the social debt domain as a form of Toraja society's social capital based on the value of spirituality is characterized by a legendary value culture not only in the culture of the Toraja community but also in the culture of the community that lives in the South Sulawesi region, namely siri'. The consequences that arise from families who owe not pay off debt from the material side do not have an impact on the family because there is no legal effect in it. However, social sanctions in the form of family shame become a matter that has an impact on the reality of family life later. The concept of values that helped enable the Rambu Solo' cultural tradition to remain strong stood strong, timeless, and still exists, coloring the Indonesian cultural tradition that is full of accounting values.

\section{REFERENCE}

[1] Alkire, S, A Bebbington, T Esmail, E Ostrom, M Polski, A Ryan, J Van Domelen, W Wakeman, dan P Dongier (2001) "Community Driven Development” World Bank Draft for Comments

[2] Atkinson, P, 1988, Ethnomethodology: A Critical review Journal Annual Review of Sociology, 14, 441-465

[3] Ahmed, E A 1994 Accounting Postulates and Principles from an Islamic Perspective Review of Islamic Economics, 1, Vol 3, No 2, hlm 1-18

[4] Bourdieu, Pierre [1983](1986) “The Forms of Capital”, dalam J Richardson, ed Handbook of Theory and Research for the Sociology of Education Westport, CT: Greenwood Press

[5] Capra, M Umer \& Ahmed, Habib 2002 Corporate Governance in Islamic Financial Institutions Occasional Paper No 6, (Islamic Research and Training Institute/Islamic Development Bank, Jeddah

[6] Carroll, Thomas F (2001) "Social Capital, Local Capacity Building, and Poverty Reduction" (Social Development Papers No 3, Office of Environment and Social Development, Asian Development Bank)

[7] Chand, P, 2012, The Effects Of Ethnic Culture And Organizational Culture On Judgments Of Accountants, Advances In Accounting, Incorporating Advances In International Accounting, Vol 28, 298-306

[8] Chariri, Anis 2009 Studying Financial Practices Within Cultural Perspective: A Note For Doing Research In Indonesian Environment Jurnal MAKSI UNDIP Vol 9, No2, h 115-138

[9] Coleman, James S (1988) 'Social capital in the Creation of Human Capital' American Journal of Sociology 94: S95-S120

[10] Coleman, James S (1990) Foundations of Social Theory Cambridge, Mass: Harvard University Press

[11] Coulon, A, 2008, Etnometodologi, Cetakan Ketiga, Penerbit Lengge:Kelompok Kajian Studi Kultural (KKSK) Jakarta dan Yayasan Lengge Mataram, Penerjemah Jimmy PhPAAT

[12] Damayanti, Ratna Ayu 2009 Hubungan Keagenan Pemerintahan Daerah Dalam Konteks Anggaran Fakultas Ekonomi Unhas Makassar

[13] Damayanti Ratna Ayu, Rahmawati and Tenriwaru 2017 Ethnographic Agency Relationship in The Context of Budget: Portrait of Local Wisdom Harmonization in Bali Pakraman Village, Journal homepage: wwwgatrenterprisecom/ GATRJournals/indexhtml

[14] Fukuyama, Francis (1995) Trust: The Social Virtues and the Creation of Prosperity New York: The Free Press

[15] Fukuyama, Francis (2001) "Social Capital and Development: The Coming Agenda" Makalah pada Konperensi "Social Capital and Poverty Reduction In Latin America and The Caribbean: Toward A New Paradigm"Santiago, Chile, September 24-26, 2001

[16] Garfinkel, H, 1967 Studies in Ethnomethodology Prentice Hall Inc New Jersey

[17] Garrison, H, Ray, Eric W Noreen, And Peter C Braver, 2006 Managerial Accounting, Seventh Edition, McGraw-Hill/Irwin, New York

[18] Gilson, L, 2006, Trust In Health Care: Theoretical Perspectives And Research Needs, Journal Of Health Organization And Management, Vol 20, No 5, pp 359-375

[19] Gittel, Ross dan J Phillip Thompson (2001) “Making Social Capital Work: Social Capital and Community Economic Development” dalam Saegert, Susan, J Phillip Thompson and Mark R Warren (eds) Social Capital and Poor Communities New York: Russell Sage Foundation, pp 115-135

[20] Goetz, J P, \& LeCompte, M D 1984 Ethnography and qualitative design in educational research Orlando, FL: Academic Press

[21] Gray, Sidney 1988 Towards a Theory of Cultural Influence on the Development of Accounting Systems Internationally

[22] Hwang, B, Jack Tsai, Hsiao-Cheng Yu and Shih-Chi Chang, 2011, An Effective Pricing Framework In A Competitive Industry: Management Processes And Implementation Guidelines, Journal of Revenue and Pricing Management Vol 10, No 3, 231-243

[23] Jackson, SE, And EB Alvarez, 1991, Working Through Diversity As A Strategic Imperative, In Jackson, SE (Ed), Diversity in the Workplace: Human Resource Initiatives, Guilford Press, New York, NY, pp13-29

[24] Jeacle, I 2009 Accounting dan Everyday Life: Towards A Cultural Context For Accounting Research Qualitative Research in Accounting and Management, Vol 6, No 3, hlm 120-136 
[25] Kieso, D E, Weygandt, J J, \& Warfield, T D 2011 Intermediate Accounting, (Jilid 1) Edisi ke-12 Diterjemahkan oleh Emil Salim Jakarta: Erlangga

[26] Kissinger, Henry Diplomacy Simon \& Shcuster paperbacks New York 1994

[27] Matthews Michael R 1993 Constructivism and Science Education: Some Epistemologi Problems Journal of Science Education and Technology March 1993, Volume 2, Issue1, pp 359-370

[28] Mathews, MR and MHB Perera, 1993, Accounting Theory and Development, Melbourne, Thomas Nelson Australia

[29] Noravesh, Iraj, Zahra Dianati Dilami, dan Mohammad SBazaz 2007 The impact of culture on accounting: Does Gray's ModelApply To Iran? Review of Accounting and Finance, Vol6, No3, h 254-272

[30] Panggarra, R 2014 Konflik Kebudayaan Menurut Teori Lewis Alfred Coser Dan Relevansinya Dalam Upacara Pemakaman (Rambu Solo'’) Di Tana Toraja Jurnal Jaffray, Vol 12, No 2, hlm 291-316

[31] Panjaitan, Hondi 2014 Pentingnya Menghargai Orang Lain HUMANIORA Vol 5, No 1 April Hal: 88-96

[32] Putnam, Robert dengan Robert Leonardi dan Rafaella Nanetti (1993) Making Democracy Work: Civic Traditions in Modern Italy Princeton, NJ: Princeton University Press

[33] Putnam, Robert (1993) "The Prosperous Community: Social Capital and Public Life," The American Prospect, 13 (Spring 1993): 35-42

[34] Saegert, Susan, J Phillip Thompson and Mark R Warren, eds (2001) Social Capital and Poor Communities New York: Russell Sage Foundation

[35] Syarifuddin dan Damayanti Ratna Ayu 2015 Story of Bride Price: Sebuah Kritik Atas Fenomena Uang Oanaik Suku Makassar Jurnal Akuntansi Multiparadigma Vol 6, No 1Hlm 79-98

[36] Sylvia 2014 Membawa Cinta Untuk Akuntansi Jurnal Akuntansi Multiparadigma (JAMAL) Volume 5, Nomor 1 Hal: 1-160 Malang, April

[37] Sztompka, Pyotr (1999) Trust: A Sociological Theory Cambridge, UK: Cambridge University Press

[38] Tangdilintin, LT 1981 Toraja dan Kebudayaanya Toraja: Yayasan Lepongan Bulan

[39] Tumirin, dan Ahim, Abdurahim 2015 Makna Biaya Dalam Upacara Rambu Solo' Jurnal Akuntansi Multiparadigma (JAMAL) Volume 6, Nomor 2 Hal: 175-184 Malang, Agustus

[40] Yulius, N A 2012 Penentuan Harga Jual Kerbau Belang Berdasarkan Karakteristik Di Pasar Hewan Bolu Kecamatan Tallunglipu Kabupaten Toraja Utara Universitas Hasanuddin, Makassar Retrieved from http://repositoryunhasacid/handle/123456789/2072. 